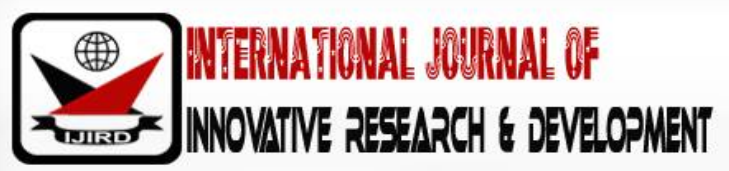

ISSN 2278 - 0211 (Online)

\section{Influence of Tokenism in Sustainability of Rural Community Water Projects in Kenya}

\begin{tabular}{|c|} 
Charles Kyale Kisumbi \\
Post Graduate Student, Project Planning and Management \\
School of Business and Economics, Moi University, Kenya \\
Peter Isamboke Omboto \\
Associate Professor, Department of Quantitative Studies \\
School of Business and Economics, Moi University, Kenya
\end{tabular}

\begin{abstract}
:
In Africa today, a lot of water is needed to achieve sustainable development in rural communities. To a great extent, community water projects have failed to offer the highly needed solutions. Water scarcity experiences in many countries had shown that community water projects did not yield enough water, and those still in operation were functioning with many inherent problems. Pervasive poverty is still experienced in many Kenyan communities today. This has affected the socioeconomic development wellbeing of rural communities. The Arnstein's Ladder Theory of Citizen Participation was adopted to guide the study and descriptive research design was used as a road map. The study investigated on the Influence of Tokenism in Sustainability of Water Projects, in empowering communities to achieve sustainable development. The specific research objective of the study was to evaluate the influence of tokenism in sustainability of community water projects. The study sample was selected by systematic sampling. Self-administered questionnaires were used to collect data and descriptive and inferential statistical measures were used to analyse the data. In the study, Tokenism and Sustainability of Community Water Projects was significant at 0.01 level, correlated at level of 0.000 . This confirmed that the regression F-test in the two variables $\left(R^{2}=0.251\right)$ with $F=0.004$ and 46 degrees of freedom the test was significant. The $p$-value of 0.004 further confirmed the test was significant, meaning that Tokenism affected sustainability of community water projects. The study revealed that households did not participate fully in the initiation and implementation of water projects to solve the inherent water problems. The study found out water scarcity had not been eradicated or mitigated to manageable levels in the study area.
\end{abstract}

Keywords: Sustainability of water projects, development projects, citizen participation, tokenism: informing, consultation and placation

\section{Introduction}

The study investigated on the influence of tokenism in sustainability of community water projects in Makueni County Kenya. The Arnstein's ladder Theory of Citizen Participation Tokenism Part was used in the study. It was clearly depicted by Pink (2012) that water is a natural resource that is very important to human life on the planet earth vital for supporting and sustaining all life. Carter (2007) described water on the planet earth being fundamental to biosphere healthy life, human health and social well-being on economic development and growth in developing countries. Further, Carter (2007) said that fresh water resources were poorly managed and polluted in the midst of watchful eye of key water policymakers. Rural communities needed to be emancipated from vicious circle want of basic life sustenance and be empowered economically through the power of tokenism (informing, consultation and placation) to manage and sustain their water projects efficiently and effectively for sustainable community development. Water is very important in achieving a faster sustainable development which impacts positively on socio-economic wellbeing of the community. In order to hasten the wheels of community sustainable development, water should always be readily available for all community needs.

There has been many inherent misunderstanding on how communities should be empowered to attain the much needed sustainable development. Muthuri et al (2009) brings to light existence of community development agenda criticisms influenced by socio-political patronage and insensitive institutionalization of participatory process affecting local priorities which are seen as vital in empowering people. Khwaja (2004) said such emergence criticisms exacerbated by political vested 
interests had affected negatively community participation thus leading to worse project outcomes. Riddell (2013) shows these criticisms, doubts and scepticisms existing in local policies and compounded by foreign aid policies which conflicted with political patronage vested interests on best ways to empower rural communities. Percy-Smith (2006) said that positive attitude of stakeholders' traditional values were important for the needed support in executing government policy and implementation of sustainable development projects.

Mulwa (2010) in his book showed project experts do sometimes treat communities as mere passive-recipient objects in quick fixing of pressing needs without involving them to participate directly in decision making. Palmer (2006) young people should be engaged in civic education, employment and cultural development to participate adequately since they are sensitive to participatory practices. Bilenky (2009) water projects should be treated as essential utility service that should be easy to operate, maintain and sustain. Mulwa (2010) community involvement increases engagement in capacity building and influences control of deployed resources in giving a sense of real ownership. The beneficiaries of any facility should be involved at various stages of a project to build relationships and to intensify participation that would in turn contribute to sustainability, (Ngowi \& Mselle, 1998). Hall (2006) professional ability and capacity in handing over of community water projects by experts is key to transferring experiences to manage projects efficiently, when outside experts and donors withdraw from community projects.

Good decision making processes and a participatory inquiry were given as good drivers for a cohesive community which increases social support and knowledge of project needs, (Nkansa \& Chapman, 2006). Project outcomes depend on good participation when supported by development specialists who able to source for further external funding and expertise, (Nkansa \& Chapman, 2006). A major focus of concern should be on external partnerships to compliment local available resources, (Ngowi \& Mselle, 1998). Transparent planning and sustainable participation in a socially cohesive community will always be able to utilize efficiently the locally available resources, leadership and community management skills, (Ngowi \& Mselle, 1998). It was shown by Rao (2009) that community programmes are more effective in an environment of decentralized decision making system that mobilizes grass root support to satisfy local needs.

Muthuri et al. (2009) participation should address social responsibility in projects to increase interrelationships important for doing project activities together. Berner et al. (2011) community activities in local government are advocated effectively by use of citizen participation in reducing the level of citizen distrust and educate the citizens on prevailing government policy. Berner et al. (2011) Citizen Participation in development projects also enhances public support and trust increasing participation efficiency in the local community. Cupps (1977) there has been several participation emerging issues and trends and changing group dynamics driven by intense political lobbying for community development projects. Furthermore, Auer (2000) said that information gathered from residents will and help to facilitate understanding on how global communities should participate in local organizations to transfer relevant knowledge and expertise.

White et al. (2005) rural water projects need to be funded through cost-sharing between the residents and the government for long term sustainability. White et al. (2005) traditional sources of water should be charged for use by the community associations to avail funds for operation and maintenance costs. Myers (1995) residents should participate fully in development projects and aim to solve literacy crisis by use of cultural intellectual resources available in the community. Kennedy et al (2009) research should be conducted on benefits of involving active community participation partnerships which are reducing injustices and disparities.

O'Reilly (2010) Effective participation leads to progress in meeting the world's Millennium Development Goals (MDGs), which is an integral part in supply of water and sanitation in communities. This way, development projects are not left to suffer, stall or collapse after the donor withdrawals from projects, (Almansi \& Tammarazio, 2008). It was shown by the World Bank (2000) that climatic changes, environmental degradation, sharp increase in world populations and extensive reduction of forest cover affected immensely water catchment towers in many developing nations. Khwaja (2004) projects do fail due to lack of sustainability and refusal of improving the non-technical part in the community which influences project activities.

Participation also reduces unnecessary delays in saving time and costs solving community problems, (Ngowi \& Mselle, 1998). Participation promotes cooperation, agreement, interaction and smooth flow of project services between the project agency and the community, (Ngowi \& Mselle, 1998). Criticisms still exist showing that participation has not been effective in targeting the needs of the poor communities adequately, (Mansuri \& Rao, 2004). Khwaja (2004) criticisms had emerged showing that increasing community participation in technical decisions of projects would lead worse project outcomes, which has been refuted by many scholars. Riddell (2013) collaborates these criticisms showing doubts and scepticism on local policies and foreign aid policies do conflict in best ways on better management practices in projects. Mulwa (2010) project experts and donors do treat communities as mere passive-recipient objects in quick fixing of pressing needs in the community without involving them to directly participate in decision making.

Challenges in participation should be overcome by building communal trust in jointly doing project initiatives together, (Bos and Brown 2015). Mulwa (2010) participation can only be achieved successfully through consulting donors and experts for collective project designs which residents are able to operate and maintain without much assistance from outsiders. Moreover, Neuse (1983) had shown the importance of citizen participation being an efficient unifying factor at grassroots level in mobilizing for project resources and community support. Beverlee (1992) the theory of citizen participation is twice important in everything as it has an empowering practical revelation and vision in putting people 
together before starting any project activity. Entwisle (2007) putting people together in place has became explosive in all empirical research work in acquiring new knowledge to combat challenges in today's communal life.

\section{Theoretical Framew ork}

The Theory of Citizen Participation Ladder Tokenism Part (informing, consultation and placation) variable was adopted to guide the study. The theoretical framework is the descriptive part of a theory adopted for a study and organized in form of a conceptual framework into which the theory variables are operationalized to give independent variables to one dependent variable, Chinn \& Kramer (1999). Torraco (2004) explained that theories were formulated for understanding in many cases to introduce, describe, predict and explain the phenomena under study explicitly or implicitly in order to challenge and the extend existing knowledge within the study bounding assumptions. Torraco (2004) a theory should be straightforward and simple in explaining what the phenomenon is and how it works in identifying the main ideas or concepts and stating clearly the relationships of the concepts between independent variables and one dependent variable. Wilcox (1994) the Theory offers a sense of urgency, empowerment and commitment in putting people together towards a common goal. Wilcox (2006) this way, the Theory enhances the active togetherness in groups to satisfy common community needs. Wilcox (2006) the Theory of Citizen Participation concept entails viewing the community as a single body with a view of empowerment capabilities to initiate community development projects in all spheres of community life. Wilcox (2006) the idea concept behind the Theory of Citizen participation is to increase participation in initiating self-help group's reliance through effective community participation in projects. Wilcox (2006) the Theory thus, is an unsurpassable guide that liaises and puts communities to act together as one body when participating in development projects.

Dublin (1976) explained that "theories were developed because the aspects of real-world were so complex that they needed to be conceptually simplified in order to be clearly understood". Dublin (1976) showed that a well-constructed theory gave clarity to complex phenomenon in real world situations by providing a system of understanding ideas and relationships. Dublin (1976) explained theory is an essential study model which gives clarity to real-world complex phenomenon difficult to understand if not simplified. Dublin (1976) "for this reason, a simple, elegant theory that makes the real-world comprehensive is preferable to a complex, elaborate theory".

Informing creates an awareness by sensitizing people to pull together towards a common goal to meet community goals and objectives. Informing is a two-way communication process between the community and project promoting agencies. The informing part in Tokenism is an essential component for smooth flow of information to prevent criticisms and mistrusts. It is in essence concerns giving away where there are no tangible ways of reaching a community. Informing is important for a continuous exposure of ideas and flow of ideas between the community and the project promoting agency. Informing the community is essential for support and awareness. Informing is a two-way communication process from the government appointed agency to empower the community in development projects. Bolitho (2005) Informing by two-way communication sharing of ideas flows ideas from the government and appointed agencies to empower on the best processes in utilization of human and capital resources. Bolitho (2005) Two-way communication exchanges project information ideas to empower people. Bolitho (2005) information is a powerful tool in community participation and also assists in decision-making basis for knowledge and capacity building in stakeholder participation. Bolitho (2005) dissemination of project information ideas involves informing in one or two-way communication under certain timeframes. Bolitho (2005) community education and literacy enhances faster the process of communication by creating understanding on project partnership of ideas with the community and the promoting agency.

Consultation in Tokenism entails conferring a fair treatment between the government and the community in public enquiries and project meeting. When communities are consulted, they end up feeling much honoured and valued. Consultation is very good practice important for what should be done in utilization of human and capital resources in guiding of public water policy and support initiatives which create understanding.

Wilcox (2006) the government support is essential for policy guidance and legislation in development projects. Wilcox (2006) the Theory of Citizen Participation ladder on public consultation support and policy is one of tokenism to pacify conflicts when participating in development projects. McDonald (2006) policies are good in guiding actions and support in a controlled environment for directing way forward to attain better gender health living standards. Policies are essential in effective actions and grassroots support for giving public directions way forward for better living standards in a community (Tharp \& Holler, 2002). Public policies are safety net programmes important for devolution of responsibility and accountability in transference of local government authority control of community social programmes at the grassroots (Tharp \& Holler, 2002). The primary purpose of a policy is to involve, organize and inform community members for support of any community programme to address a need (Tharp \& Holler, 2002). Vos et al (2009) collaborates on the Theory of Citizen Participation that empowerment on community participation plays a pivotal role in empowering the community for future participation common strategies.

Vos et al. (2009) the people's approach through participation helps in influencing community power relations and diffuses popular placation pressure by adopting local government policies in order to address problems in a community. Daley et al. (2013) promoting sustainability initiatives through partnership action-oriented participation empower a community to be part and parcel of the programme initiatives in their locality. Parker (2003) consultation in conflict resolution is usually 
looking for pacifying ways of problem resolution in development projects essential for harmony and peaceful climate of mutual trust and confidence in pulling together towards a common goal. Sik (2014) Sherry Arnstein's types of community participation do concern convergence of public participation hearing of resident opinions in the resolution of conflicts in development projects. Dewan (2014) local mechanisms of local dispute resolution in water resources enhances communitybased organizations to actively participate through management of information and consultation pacifying of conflicting issues in a community.

Placation brings harmony and peace in reinforcing mutual trust between the community and government for collaboration in water projects. Placation is essential for conflict resolution in looking for assuaging anger bouts or a feeling less aggrieved. Placation concerns creating a serene working environment of mutual understanding that pulls community and project agency together towards a common goal.

According to Merriam-Webster online dictionary (2016) placation is to soothe and disarm unpleasant feeling, to appease, and to assuage making less severe or painful, to pacify in a gentle manner in causing someone to feel less angry or aggrieved about something in community. Lithgow (2006) Placation in tokenism is the beginning a degree of influencing though tokenism is still apparent in the community which entails handpicking of worthy poor community boards for transparency and accountability. Lithgow (2006) there can also be form of voting to select advisory and planning committees in order to appease and assuage unpleasant feelings that can jeopardize the community programmes. Lithgow (2006) placation is usually dictated by two factors: the quality of technical team in assistance for articulation priorities and the extent to which the community has been organized in pulling together.

\section{Conceptual Framew ork}

Figure 1 depicts the conceptual framework independent and dependent variables in the study. The study seeks to link citizen tokenism (Informing, Consultation and Placation) to sustainability of water projects through open communication channels in. The study aimed at identifying the citizen tokenism gap in sustainability of water projects.

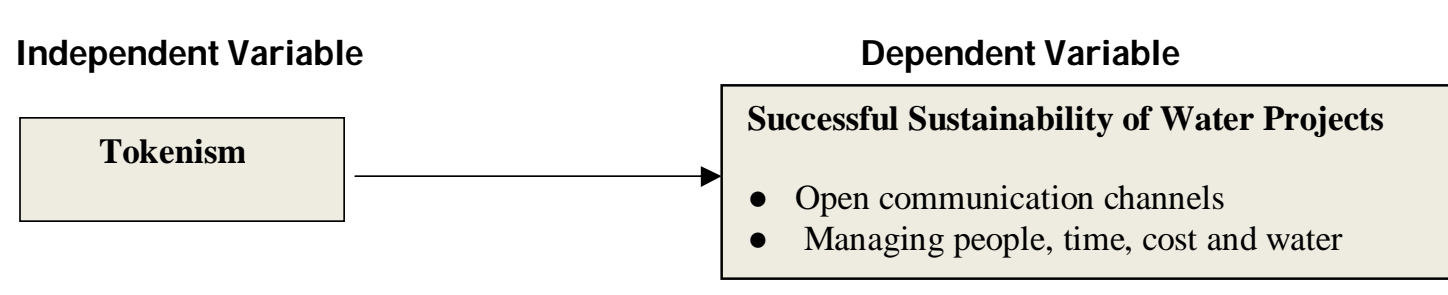

Figure 1: Conceptual Framework

\section{Methodology}

\subsection{Design}

The study adopted a descriptive research design. Mixed methods, quantitative and qualitative data was used in the study. The target population was 40,423 households served by the water projects. A sample size of $\mathrm{n}=121$ respondents was selected using systematic sampling technique. The study area was Makueni County which comprises 9 sub-counties.

\subsection{Participants}

Households (121) served by water projects in the study area the participated in the study.

\subsection{Data Collection}

Self-administered questionnaires and an interview schedule were used to collect data in the study area. A pre-test pilot study was done to ascertain validity and reliability of the questionnaires.

\subsection{Data Analysis}

Data was analysed using Statistical package for Social Sciences (SPSS). The mixed method data was analysed quantitatively and qualitatively to get results. The qualitative data was to provide more support and clarity to the study. Correlation and Regression descriptive and inferential statistical analyses were used. This research relied on descriptive statistics in order to develop a general overview of the data collected, to describe, infer and to generalize information into the entire population. The model below was used to determine the relationship between the dependent variable (Sustainability of Water Projects) and independent variable Tokenism (Informing, Consultation, Placation) as: $\mathrm{Y}=\alpha++\beta 1 \mathrm{X} 1+\mu$. Where:

$\mathrm{Y}=$ Sustainability of Water Projects and Tokenism (Informing, Consultation, Placation).

$\alpha=$ is the constant.

$\mathrm{X}_{1}=$ Tokenism (Informing, Consultation, Placation).

$\mu=$ is the unpredictable random element or error term and $\beta_{1}$, is the coefficients of $X_{1}$. 


\subsection{Ethical Considerations}

Respondents participated freely in the study and consent was obtained from those willing to participate were considered eligible for the study. The researcher promised the respondents confidentiality will be maintained at all times and no information will be divulged to third parties.

\section{Results}

\subsection{Influence of Tokenism in Water Projects Sustainability}

In evaluating the influence of tokenism in water projects sustainability in Makueni County, the adopted Ladder of Citizen Participation three variables Informing, Consultation and Placation were used. The three variables were important in understanding the influence of informing, consulting and placating thorny issues in the community participation.

\subsection{Informing and Water Projects Sustainability}

Informing in Tokenism as depicted in the ladder of Citizen Participation is an important element for measuring community participation. Informing concerns two-communication of information and feedback, response between the water projects sponsors and the community. Mutual understanding and representation between community leaders and promoting agency is key to having successful sustainability of water projects.

\subsection{Mode of Communication Delivery in Water Projects}

The mode of communication to deliver information created a deeper understanding between the community and project sponsors. Bolitho (2005) reported that information was a two-way communication process that created understanding between projects experts and the community. And further, Bolitho (2005) said that dissemination of information was a twoway communication in sharing of project ideas for better utilization of human and natural resources through participative communication to meet community goals.

Results for most preferred mode of communication in informing were: Meetings and Barazas 84 (69.4\%),

Telephone $19(15.4 \%)$, Letters $9(7.4 \%)$ and No response $8(6.6 \%)$. The results on the person who delivers information about water projects were: Community Leader 50 (41.3\%), Government official 31 (25.6\%), Personal access to information $27(22.3 \%)$, NGOs agent $1(0.8 \%)$ and no response $12(9.9 \%)$. Results on literacy level of the community of the respondents were: High literacy 25 (20.7\%), Low literacy 75 (62.0\%), Not sure $11(9.1 \%)$ and No response $10(8.3 \%)$. The literacy of the community was said to be low on what goes on in water projects. For the delivery of information, and Community leader was most preferred for delivery of information followed by the government official. The results showed meetings and barazas were most preferred mode of communication from government officials as the major channel of communication to the community. Effective communication is important in water projects as it enhances direct involvement giving understanding of how the community would participate to meets their needs.

When asked if the information on water projects was informative enough to understand the results were: No 80 (66.1\%), Yes 12 (9.9\%). Majority of respondents said did get enough information what goes on in water projects. Bolitho (2005) said information enhanced community education and literacy for faster communication between the community and the promoting agency.

\subsection{Gender discrimination and Water Conflict Situation}

In the empirical studies, discrimination has been reported on access to water due to water conflicts. The results for gender discrimination in water projects were: No response 45 (37.2\%), Insensitive water committees 27 (22.3\%), Privy to project resources 15 (12.4), Men or Women want control 12 (9.9\%), Leadership disparity 15 (12.4\%) and transparency and accountability issues 7 (5.8\%). Parker (2003) showed that conflict resolutions in water projects could be handled well through participatory consultative processes to bring harmony, peace, mutual trust and confidence in communities.

On accountability and transparency in development projects, (Tharp \& Holler 2002) said that public policies were best safety nets for transference of government programmes and devolution responsibility ideals to local communities at grassroots. When asked what would alleviate the water problem and conflicts, the results were: Open communication channels 32 (26.4\%), More water projects implementation 28(23.1\%), Community Training 27(22.3\%), transparent and accountability 17(14.0\%), Giving in cash and in kind 4(3.3\%) and No response 13(10.7\%). Bolitho (2006) showed open communication was a major tool in alleviating water problems in the community as many did not have enough information on what goes on in water projects.

\subsection{Consultation and Water Projects Sustainability}

Consultation under Tokenism in water projects involves dialogue and discussion through exchange of information to reach an understating consensus of what should be done for mutual benefit in Community Participation. It is important to understand the willingness to be consulted of the community in water projects that will meet water needs. Consultation is a measurable variable in the sustainability of water projects. 


\subsection{Community Consultation Willingness, Attendance and Feedback}

Willingness to be consulted is important as well as the attendance to water meetings. Wilcox (1994) community vested interests are promoted in participation and acting together to solve issues instead of being mere spectators in water projects. When asked if the community was willing to be consulted on water projects, the respondents answered: Yes 83 (68.6\%), No $18(14.9 \%)$, Not sure $9(7.4 \%)$ and no response $9.1 \%)$. The $83 \%$ enforces the idea that consultation is very important in water projects

\subsection{Community Attendance to Consultation Sessions}

When asked if they ever attended any consultation sessions on water projects the respondents the results were: No $79(65.3 \%)$, Yes $27(22.3 \%)$, missing $1(0.8 \%)$ and no response $14(11.6 \%)$. Majority of residents did not find time to attend water consultation sessions on water projects. Attendance in water projects meetings were reported results were: Meetings usually not known $46(38.0 \%)$, Few attend $27(22.3 \%)$, many attend $26(21.5 \%)$, No one interested $9(7.4 \%)$ and no response $11(9.1 \%)$. It was reported water meetings were not known due to information delivery challenges.

\subsection{Feedback Information on Consultation Sessions}

Majority of the respondents reported that there was not feedback received on consultation sessions and that took place in community participation meetings. When asked whether Feedback views were sought the results were: No 80 (66.1\%), Yes $28(23.1 \%)$, Missing $1(0.8 \%)$, and no response 12(9.9\%). And on previous concerns raised on water projects were addressed the results showed: No 82 (67.8\%), Yes 28(23.1\%), and no response 11(9.1\%). Communities must be brought together as Wilcox (2006) said community participation should be used as tool to laisse community with sponsors in development programmes.

\subsection{Placation and Sustainability of Water Projects}

Placation in the ladder of Citizen Participation is essential for disarming community unpleasant feeling by soothing them to create a climate of peace and harmony. Placation brings in the ideas of lessening pain and agony in water projects by pacifying in a gentle manner any conflicts, whether perceived or real. It involves a way of placating various community criticisms and conflicts to give a serene environment for all the people to be treated fairly in water projects. Lithgow (2006) praised Placation as having strong transparent influence when selecting by vote and handpicking community boards to represent the community. Lithgow (2006) advised care should be taken at placation stage of community participation since it dictated important two factors: the quality of the technical team to articulate priorities and the extent in which the community was organized.

\subsection{Placation as a conflict mitigating measure in Water Projects}

Placation concerns disarming negative opinions and mitigating adverse effects of community conflicts, perceived or real that may hinder breakthroughs and mutual understanding in water projects. Understanding the water situation in water projects is of major importance in reaching out to the community in their water needs through community participation. Lithgow (2006) shows that placation influences positively community boards in areas of transparency and accountability. The water situation results were: Bad $42(34.7 \%)$, Moderate scarcity of water $36(29.8 \%)$, Severe scarcity of water $31(25.6 \%)$, No response 7 (5.8\%), Do not know 3 (2.5\%) and the least Good 2(1.7\%).

The results of the 121repondnets of unfair treatment in water projects were, Yes 60 (49.6\%), No 51 (42.1\%) and No response $10(8.3 \%)$. Majority of respondents were mistreated in the water projects through unfair sharing water across the water projects. In order to succeed Lithgow (2006) placation is usually dictated by two factors; the quality of team in articulation of assistance priories to the community and the extent in which the community has been organized in pulling together as one in water projects.

\subsection{Mistreatment and Solving Water Conflicts}

Different types of mistreatment were reported in water projects. It is possible to reduce this as said (Ngowi \&Mselle, 1998) it involved promoting cooperation, agreement and interaction between the project agency and community reduces many problems in water projects. Kinds of Mistreatment Experienced in Water Projects results were: Bad verbal Language 67 (55.4\%), No response 24 (19.8\%), Unfair water sharing 22 (18.2\%), High water charges 6 (5.0\%) and Water conflicts 2 (1.7\%). Mistreatment experienced was reported as bad verbal language in water projects. Results on water conflicts were: No 66 $(54.5 \%)$, Yes $46(38.0 \%)$ and No response $9(7.4 \%)$. The water conflicts were reported average. Results on the issue of how water conflicts were solved, the respondents said: Electing new leaders 44(36.4\%), No response 42(34.7\%), Do not know 24(19.8\%), Boycotting due to fights $6(5.0 \%)$ and involving police $5(4.1 \%)$. The respondents how on water projects committees were selected: Majority vote 50 (41.3\%), Do not know 27 (22.3\%), Hand-picking 24 (19.8\%), No response 12 (9.9\%), Self-imposition 7 (5.8\%) missing $1(0.8 \%)$. Voting was said to be the best method to select water committees. It has been shown that (Ngowi \&Mselle, 1998) Complexities of technology adopted and poor water systems create a hindrance in early stages of a project through breakdowns or operation. 


\subsection{Decision making Influences on Quality and Quantity Water}

Decision making is very important for placating and conflicting issues community participation. When asked whether the residents had influence on decisions in water projects, the results were: Yes 61 (50.4\%), No 48 (39.7\%), missing 1(0.8\%), and No response 11(9.1\%). Sultana (2009) depicted that Community Participation influenced decision making by increasing spatial gender power relationships and mitigating conflicts. When asked how decisions were made in water projects, the respondents answered decisions were made by: General meeting 41 (33.9\%), Elected officials 19 (15.7\%), Do not know 17(14.0\%), No response 11(9.1\%), Government officials 8 (6.6\%), Donors/sponsors 7(5.8\%), Water projects implementers 5(4.1\%) and Missing 7 (5.8\%).

The quality and quantity of water was not good enough according to the residents. Figure 4.10 shows the results of quality and quantity of water in water projects were, Bad 76 (62.8\%), Good 22(18.2\%), Very Good 6(5.0\%), Excellent 4(3.3\%), Do not know $3(2.5 \%)$ and No response $10(8.3 \%)$. Water from water projects was said by the majority to be very bad as it changed colour within 24 hours. The quality of water operators was said to be bad as results showed, Bad 74 (61.2\%), Good 31(25.6\%), No response 8 (6.6\%), Excellent 3(2.5\%), Do not know 3 (2.5\%) and Very good 2(1.7\%). Decision making in water projects according to O'Reilly (2010) depends on effective participation in meeting world's Millennium Development Goals (MDGs).

\subsection{Transparency and Accountability in Water Projects Sustainability}

In order for placation to function optimally when households participate in water projects, there must be transparency and accountability in word and indeed. Results on transparency and accountability Bad 70 (57.9\%), Good 23 (19.0\%), Excellent 9(7.4\%), No response 9(7.4\%), Do not know 6(5.0\%), and Very good 4(3.3\%). Transparency and accountability was bad in the sustainability of water projects.

Results on gender wrangles in water projects, No 78 (64.5\%), Yes 30 (24.8\%) and No response 13 (10.7\%). Gender wrangles and conflicts were reported in water projects. Tharp \& Holler (2002) reported transparency and accountability was important in the devolution and sustainability community programmes as it created a safety net in placating thorny issues in the community.

\subsection{Relationship between Tokenism and Sustainability of Water Projects}

In the ladder of Citizen Participation, Tokenism Part is composed of Informing, Consultation and Placation.

\begin{tabular}{|c|c|c|c|c|c|}
\hline \multicolumn{2}{|c|}{ Tokenism } & Informing & Consultation & Placation & Sustainability Of Water Projects \\
\hline \multirow{4}{*}{ Informing } & $\begin{array}{c}\text { Pearson } \\
\text { Correlation }\end{array}$ & 1 & -.163 & -.220 & -.079 \\
\cline { 2 - 6 } & Sig. (2-tailed) & & .239 & .110 & .577 \\
\cline { 2 - 6 } & $\mathrm{N}$ & 55 & 54 & 54 & 52 \\
\hline Consultation & $\begin{array}{c}\text { Pearson } \\
\text { Correlation }\end{array}$ & -.163 & 1 & .112 & .040 \\
\cline { 2 - 6 } & Sig. (2-tailed) & .239 & & .254 & .691 \\
\cline { 2 - 6 } & $\mathrm{N}$ & 54 & 110 & 105 & 103 \\
\hline Placation & $\begin{array}{c}\text { Pearson } \\
\text { Correlation }\end{array}$ & -.220 & .112 & 1 & $.416^{* *}$ \\
\cline { 2 - 6 } & Sig. (2-tailed) & .110 & .254 & & .000 \\
\cline { 2 - 6 } & $\mathrm{N}$ & 54 & 105 & 111 & 103 \\
\hline \multirow{3}{*}{$\begin{array}{c}\text { Sustainability of } \\
\text { water projects }\end{array}$} & $\begin{array}{c}\text { Pearson } \\
\text { Correlation }\end{array}$ & -.079 & .040 & $.416^{* *}$ & 1 \\
\cline { 2 - 6 } & Sig. (2-tailed) & .577 & .691 & .000 & 108 \\
\cline { 2 - 6 } & $\mathrm{N}$ & 52 & 103 & 103 & \\
\hline
\end{tabular}

Table 1: Relationship between Tokenism and Sustainability of Community Water Projects Correlations

** Correlation is significant at the 0.01 level (2-tailed)

Source: Researcher (2016), Table 1.1 shows correlation between Tokenism (Informing, Consultation and Placation) and Sustainability of Water Projects.

Lithgow (2006) showed the kind of 'Clinical Group Therapy' as a mental illness cure to inject therapeutic group synergies in community participation masked in Citizen Participation ladder. Lithgow (2006) said this was essential for guidance and beneficial in reawakening and reenergizing mental capacities for the powerless in the community to participate fully in development projects. Once project sponsors and implementers involve the community to participate, a step steps on Non-participation ladder two rungs of Manipulation and Therapy, a small change is felt moving upwards, towards sustainability of water projects. This is a step towards satisfaction of households' water needs.

From the above table it is evident that the three variables, informing, consultation and placation (all representing Tokenism, the independent variable) are weakly related with $-0.79,0.40$ and 0.416 as correlation coefficients. Correlation is significant at the 0.01 level (2-tailed) between Tokenism and Sustainability of Water Projects. The Tokenism, three variables were chosen and correlation test run and the results were obtained in Table4.20. However, with placation having a higher positive coefficient of 0.416 it 
is chosen to be the independent variable to stand for the larger independent variable, Tokenism. The correlation coefficient 0.416 shown in Table 4.20 is a positive weak relationship. Correlation is significant at the 0.01 level (2-tailed). This is because, the two variables Tokenism and Water Projects Sustainability are significantly correlated at 0.040 as shown in Table 4.21, meaning that the households in order to participate fully needed Tokenism (Informing, Consultation, Placation) to function properly in sustainability of water projet.

\begin{tabular}{|c|c|c|c|c|c|c|c|c|c|}
\hline \multirow[t]{2}{*}{ Model } & \multirow[t]{2}{*}{$\mathbf{R}$} & \multirow{2}{*}{$\begin{array}{c}\text { R } \\
\text { Squa } \\
\text { re }\end{array}$} & \multirow{2}{*}{$\begin{array}{l}\text { Adjusted } \\
\text { R Square }\end{array}$} & \multirow{2}{*}{$\begin{array}{c}\text { Std. } \\
\text { Error of } \\
\text { the } \\
\text { Estimate }\end{array}$} & \multicolumn{5}{|c|}{ Change Statistics } \\
\hline & & & & & $\begin{array}{c}\text { R Square } \\
\text { Change }\end{array}$ & $\begin{array}{c}\mathbf{F} \\
\text { Change }\end{array}$ & df1 & df2 & Sig. F Change \\
\hline 1 & $.501^{\mathrm{a}}$ & .251 & .203 & .909 & .251 & 5.149 & 3 & 46 & .004 \\
\hline
\end{tabular}

a. Predictors: (Constant, Placation, Consultation, Informing).

Source Researcher $(2016$

Table 2 confirms the linear regression's F-test that there is a linear relationship between the two variables (in other words $\mathrm{R}^{2}=0.251$ ) with $\mathrm{F}=0.004$ and 46 degrees of freedom the test is significant, thus we can assume that there is a linear relationship between the variables Tokenism and sustainability in our model.

\section{Coefficients}

\begin{tabular}{|c|c|c|c|c|c|c|c|}
\hline \multirow{2}{*}{$\begin{array}{l}\text { Model Water } \\
\text { projects } \\
\text { sustainability }\end{array}$} & \multicolumn{2}{|c|}{$\begin{array}{l}\text { Unstandardized } \\
\text { Coefficients }\end{array}$} & \multirow{2}{*}{$\begin{array}{c}\begin{array}{c}\text { Standardized } \\
\text { Coefficients }\end{array} \\
\text { Beta }\end{array}$} & \multirow[t]{2}{*}{$\mathbf{t}$} & \multirow[t]{2}{*}{ Sig. } & \multicolumn{2}{|c|}{ 95.0\% Confidence Interval for $\mathrm{B}$} \\
\hline & B & $\begin{array}{l}\text { Std. } \\
\text { Error }\end{array}$ & & & & $\begin{array}{l}\text { Lower } \\
\text { Bound }\end{array}$ & Upper Bound \\
\hline (Constant) & 1.944 & .750 & & 2.593 & .013 & .435 & 3.453 \\
\hline Informing & .013 & .091 & .019 & .142 & .887 & -.170 & .195 \\
\hline Consultation & -.041 & .096 & -.055 & -.429 & .670 & -.234 & .152 \\
\hline Placation & .656 & .169 & .507 & 3.879 & .000 & .316 & .996 \\
\hline
\end{tabular}

Table 3: Regression Coefficients Tokenism and Sustainability at 95\% Level

Dependent Variable: Sustainability of water projects

Source: Researcher (2016)

Fitting the line of best fit as illustrated on Table 3, we obtain the following model:

The model is $\mathrm{Y}=\mathrm{a}+\mathrm{bx}$, where $\mathrm{a}=1.944 \mathrm{~b}=0.656$ and $\mathrm{X}=$ Tokenism.

$\mathrm{Y}=1.944+0.656 \mathrm{X}_{1}$. The regression coefficients constant and Tokenism as predictor variables and water projects sustainability as the dependent variable are shown in Table 4.20 at $95 \%$ confidence level.

\section{Hypothesis Testing on Tokenism vs Sustainability of Water Projects.}

The hypothesis stated that:

$\mathrm{HO}_{\mathrm{l}}$ : There is no significant relationship between Tokenism (Informing, Consultation and Placation) and water projects sustainability in Makueni County, Kenya.

Table 1 shows the significance level of 0.000 which is (less than 0.1).We have Strong evidence against the hypothesis which states there is relationship between Tokenism and water project sustainability, therefore we reject the null hypothesis and conclude that there is significant relationship between Tokenism and Sustainability Water Projects. The p-value of 0.004 in Table 1.1further confirms that there is significant relationship between Tokenism and Sustainability. In the study area, the households faced scarcity of water and even when available in some water projects shortages were experienced.

It was clear from the study that Tokenism (informing, consultation and placation) was lacking in water projects which led to the community not to participate adequately in sustainability of water projects that served them. Furthermore official Public participation was launched in 2016 in Makueni County and it may take time to be replicated in all existing water projects across all the water projects. This explains the minimal existence of Tokenism (Informing, Consultation, and placation) and community participation in sustainability of water projects that served households in the study area.

The households reported informing, in two-way communication feedback was no enough if not lacking and so was consultation and placation. It follows that there was little to placate in the Ladder of Citizen Participation since there was no official guidance of participation in place. In the study area, majority of households said they never attended consultation meetings when the water projects were being implemented as they belonged to the sponsors and implementers. Most households said they never knew whether there were consultation meetings and were never invited to attend. The non-awareness of consultation sessions and recent 
launch public participation affected community participation in sustainability of water projects. This explains the existence of minimal community participation in water projects. The study showed that once project sponsors stepped on the 3 ladder rungs of Tokenism (informing, consultation and placation) an upward trend change was felt though minimal, moving towards the expected sustainability of water projects in the study area.

\section{Conclusion}

The chapter draws conclusion from the findings of the study. It also makes recommendations of the findings for implementation as well as a background research study. This study will be a reference background document for further similar research studies elsewhere.

The objective of the study was to evaluate the influence of Tokenism on sustainability water projects in Makueni County, Kenya. The study adopted the variables the Ladder of Citizen Participation Theory Tokenism (informing, consultation, and placation). The Research Hypotheses stated that:

H01: There is no significant relationship between Tokenism (Informing, Consultation Placation) and Sustainability Water Projects in Makueni County, Kenya.

\section{Tokenism and water projects sustainability}

Table 1 shows Correlation is significant at the 0.01 level (2-tailed) between Tokenism and Sustainability of Water Projects. This is because, the two variables Tokenism and Water Projects Sustainability are significantly correlated at 0.040 as shown in Table 1.2, meaning that the households in order to participate fully needed Tokenism (Informing, Consultation, Placation) to function properly in sustainability of water projects in the study area. Table 2 confirms this which shows the F-test, the linear regression's F-test that there is a linear relationship between the two variables (in other words $R^{2}=0.251$ ). With $F=0.004$ and 46 s degrees of freedom the test is significant, thus we can assume that there is a linear relationship between the variables therapy and sustainability in our model.

Table 2 shows the significance level of 0.000 which is (less than 0.1).We have Strong evidence against the hypothesis which states there is no relationship between non participation and water project sustainability, therefore we reject the null hypothesis and conclude that there is significant relationship between Tokenism and Sustainability Water Projects. The P-value of 0.004 in Table 4.21 further confirms that there is significant relationship between Tokenism and Sustainability. In the study area, the households faced scarcity of water and even when available in some water projects shortages were experienced. It was clear from the study that Tokenism (informing, consultation and placation) was lacking in water projects which led to the community not to participate adequately in sustainability of water projects that served them. Furthermore official Public participation was launched in 2016 in Makueni County and it may take time to be replicated in all existing water projects across all the water projects.

Most households said they never knew whether there were consultation meetings and were never invited to attend. The nonawareness of consultation sessions and recent launch public participation affected community participation in sustainability of water projects. This explains the existence of minimal community participation in water projects. The study showed that once project sponsors stepped on the 3 ladder rungs of Tokenism (informing, consultation and placation) an upward trend change was felt though minimal, moving towards the expected sustainability of water projects in the study area.

On the basis of these findings and conclusions arrived at the researcher recommends that all the initiators and implementers of water projects should at all times involve communities to participate in water projects in their areas of residence. The collapsed water projects are clear evidence that the water projects in the study area had not been properly sustained. This may impact positively in sustainability of water projects when communities participate in water projects that will satisfy their water needs of communities. They should seek to ensure:

\section{Tokenism in Sustainability of Water Projects}

The second objective was to evaluate the influence of involvement in water projects sustainability in Makueni County Kenya. Tokenism consisted of Informing, Consultation and Placation adopted as the variable of study. The study found that the hypothesis, there was a relationship between Tokenism and water projects sustainability. This is to say that Tokenism (partnership, consultation and delegated power) should be pursued to involve the community in the sustainability of water projects. It is important for the Government and NGOs to exhaustively find out the inherent problems before establishing water projects because it can be seen that on the ground there were failed water projects and operating ones in some places were in a state of disrepair near collapsing.

\section{References}

i. Almansi \& Tammarazio (2008). Journal of Environment \& Urbanization, Florencia Almansi and Andrea Tammarazio, International Institute for Environment and Development (IIED). Vol 20(1): 121-147. DOI: 10.1177/ 0956247808089289 and www.sagepublications.com, SAGE Publications.

ii. Arnstein S.R. (1969). A Ladder of Citizen Participation in Sherry R. "A Ladder of Citizen Participation," Journal of the American Institute of Planners (JAIP), Vol. 35, No. 4, July 1969, pp. 216-22.

iii. Baker \& Palmer (2006). Examining the Effects of Perceptions of Community and Recreation Participation on Quality of Life Author(s): Dwayne A. Baker and Robert J. Palmer, Source: Social Indicators Research, Vol. 75, No. 3 (Feb., 2006), pp. 395-418 Published by: Springer Stable URL: http:/ / www.jstor.org/ stable/ 27522540. 
iv. Berner M. (2011). URL http:// Berner et al (2011). What constitutes effective citizen participation in local government? Views from city stakeholders, Maureen. Berner, Justin m. Amos, Ricardo s. Morse, Journal of Public Administration Quarterly, Vol. 35, No. 1 (SPRING 2011), pp. 128-163.

v. Beverlee P. (1992). Putting Theory into Practice: An Empowering Revelation, Beverlee Paul, the Reading Teacher, Vol. 45, No. 6 (Feb., 1992), p. 446.

vi. Bilenky W.S. (2009). An alternative strategy for water supply and water resource development in Florida, William S. Bilenky, Journal of Land Use \& Environmental Law, Vol. 25, No. 1 (Fall 2009), pp. 77-107.

vii. Bolitho A. (2005). Dr A Bolitho, Citizen's juries for natural resource management, Social Capacity Building Project Catchment Strategies, Victorian Department of Sustainability and Environment, Melbourne: http:/ / www.dse.vic.gov.au/ effective-engagement/ developing-an-engagement-plan/ types-of-engagement.

viii. Bos \& Brown (2015). Overcoming barriers to community participation in a catchment-scale experiment: building trust and changing behaviour, Darren G. Bos, Helen L. Brown, The Society for Freshwater Science, Vol. 34, No. 3 (September 2015), pp. 1169-1175.

ix. Carter J.G. (2007). Spatial Planning, Water and the Water Framework Directive: Insights from Theory and Practice, Jeremy G. Carter, The Geographical Journal, Vol. 173, No. 4, Critical Perspectives on Integrated Water Management (Dec., 2007), pp. 330-342.

x. Chinn \& Kramer (1999).Theoretical Framework vs. Conceptual Framework, StudyMode.com. Retrieved, 2011, http:/ / www.studymode.com/ essays/ Theoritical-Framework-Vs-Conceptual-Framework-825118.html.

xi. Cupps D.S. (1977). Emerging Problems of Citizen Participation, D. Stephen Cupps, Public Administration Review, Vol. 37, No. 5 (Sep. - Oct., 1977), and pp. 478-487.

xii. Daley D.M. (2013). Understanding City Engagement in Community-Focused Sustainability Initiatives, Dorothy M. Daley, Elaine B. Sharp, Jungah Bae

xiii. $\quad$ Cityscape, Vol. 15, No. 1, Climate Change and City Hall (2013), pp. 143-161

xiv. Dewan C. (2014). Dewan, C.; Buisson, M.-C, and Mukherji, A. 2014. The Imposition of Participation? The case of participatory, water management in coastal Bangladesh, Water Alternatives 7(2): 342-366. www.wateralternatives.org Volume 7, Issue 2.

xv. Dublin Simon. (1976).

https:/ / books.google.co.ke/ books?id=JUKTMx8ZeKsC\&pg=PA9\&lpg=PA9\&dq=meaning +of+theoretical+and+concept ual+framework+by+Dublin+in+1976\&source.

xvi. Hall J. (2006). Sustainable Development: A case study of Emmanuel Hospital Association's Prem Jyoti Community Health and Development Project in the State of Jharkhand, North India, Megan Hall, Transformation, Vol. 23, No. 3, Some Major Research Priorities in Transformational Development (July 2006), pp. 163-169.

xvii. $\quad$ Kennedy C. (2009). Faculty Perspectives on Community-Based Research: "I See This Still as a Journey" Author(s): Caitlin Kennedy, Amanda Vogel, Clara Goldberg-Freeman, Nancy Kass and Mark Farfel Source: Journal of Empirical Research on Human Research Ethics: An International Journal, Vol. 4, No. 2 (June 2009), pp. 3-16. Published by: Sage Publications, Inc. Stable URL: http:/ / www.jstor.org/ stable/ 10.1525/ jer.2009.4.2.3.

xviii. Khwaja A.I. (2004). Is Increasing Community Participation Always a Good Thing? Asim Ijaz Khwaja, Journal of the European Economic Association, Vol. 2, No. 2/ 3, Papers and Proceedings of the Eighteenth Annual Congress of the European Economic Association (Apr. - May, 2004), pp. 427-436.

xix. Lithgow D. (2006). URL http:// lithgow-schmidt.dk/ sherry-arnstein/ladder-of-citizen-participation.html

xx. Lithgow D. (2008). Duncan Lithgow http:// lithgow-schmidt.dk/ sherry-arnstein/ladder-of-citizen-participation.html and http:/ / lithgow-schmidt.dk/ contact-duncan-lithgow .

xxi. Mansuri \& Rao (2004). Community-Based and -Driven Development: A Critical Review Community-Based and -Driven Development: A Critical Review, Ghazala Mansuri, Vijayendra Rao, the World Bank Research Observer, Vol. 19, No. 1 (spring, 2004), pp. 1-39.

xxii. McDonald P. (2006). Peter McDonald, An Assessment of Policies that Support Having Children from the Perspectives of Equity, Efficiency and Efficacy, Vienna Yearbook of Population Research, Vol. 4, Postponement of Childbearing in Europe (2006), pp. 213-23.

xxiii. Merriam-Webster Online Dictionary (2016). http:// www merriam-webster.com

xxiv. Mulwa F.W. (2010). Demystifying participatory Community Development 2nd Ed. Paulines Publications Africa, Nairobi, Kenya.

xxv. Muthuri \& Moon (2009). An Integrated Approach to Implementing 'Community Participation' in Corporate Community Involvement: Lessons from Magadi Soda Company in Kenya, Judy N. Muthuri, Wendy Chapple, Jeremy Moon, Journal of Business Ethics, Vol. 85, Supplement 2: Corporate Social Responsibility Implementation (2009), pp. 431-444.

xxvi. Myers M. (1995). Why Participate? Miles Myers, College Composition and Communication, Vol. 46, No. 3 (Oct., 1995), pp. 438-440.

xxvii. $\quad$ Neuse S.M. (1983). From Grass Roots to Citizen Participation: where we've been and where we are now, Steven m. Neuse, Public Administration Quarterly, Vol. 7, No. 3 (FALL, 1983), pp. 294-309. 
xxviii. $\quad$ Ngowi \& Mselle (1998). Ngowi A.B., Mselle P.C., Community participation in facility management, Facilities, Volume: 16 Issue: $11,1998$.

xxix. $\quad$ Nkansa \& Chapman, 2006. Sustaining Community Participation: What Remains after the Money Ends? Grace Akukwe Nkansa, David W. Chapman, International Review of Education / Internationale Zeitschrift für Erziehungswissenschaft / Revue Internationale de l'Education, Vol. 52, No. 6 (Dec., 2006), pp. 509-532.

xxx. O'Reilly K. (2010). Combining Sanitation and Women's Participation in Water Supply: An Example from Rajasthan, Kathleen O'Reilly, Development in Practice, Vol. 20, No. 1 (Feb., 2010), pp. 45-56.

xxxi. Palmer, Watson \& Watson (2006). "Going Back to Country with Bosses": The Yiriman Project, Youth Participation and Walking along with Elders, David Palmer, John Watson, Anthony Watson, Peter Ljubic, Hugh Wallace-Smith, Mel Johnson, Children, Youth and Environments, Vol. 16, No. 2, Pushing the Boundaries: Critical International Perspectives on Child and Youth Participation - Focus on Europe, Australia, and New Zealand/ Aotearoa (2006), pp. 317-337.

xxxii. Percy-Smith B. (2006). Percy-Smith, Barry, From Consultation to Social Learning in Community Participation with Young People Children, Youth and Environments, Vol. 16, No. 2, Pushing the Boundaries: Critical International Perspectives on Child and Youth Participation - Focus on Europe, Australia, and New Zealand/ Aotearoa (2006), pp. 153-179.

xxxiii. Pink R. (2012). Child rights, water rights and human security, Ross Pink, Health and Human Rights, Vol. 14, No. 1 (June 2012), pp. 78-87.

xxxiv. Rao V.S. (2009). Lack of Community Participation in the Sarva Shiksha Abhiyan: A Case Study, Vasanta Srinivasa Rao, Economic and Political Weekly, Vol. 44, No. 8 (Feb. 21 - 27, 2009), pp. 61-64.

xxxv. $\quad$ Riddell R.C. (2013). "Does Foreign Aid Work?" (pp. 47-80), From: Doing Good or Doing Better, Roger C. Riddell, Amsterdam University Press (2009).

xxxvi. $\quad$ Rosegrant \& Gazmuri (1995). Reforming water allocation policy through markets in tradable water rights: lessons from Chile, Mexico, and California, Mark W. Rosegrant, Renato Gazmuri S., Cuadernos de Economía, Año 32, No. 97 (Diciembre 1995), pp. 291-315.

xxxvii. Sik K. (2014). KIM Kwang Sik, KIM Gyeng Chul, and SONG Seok-Hwi, https:/ / books.google.com/ books?isbn=895503637X.

xxxviii. Tharp \& Holler (2002). Engaging Community Members in Health Policy Processes: a Mississipp1 example, Brian Tharp, Danielle Holler, Journal of Health and Human Services Administration, Vol. 24, No. 4 (SPRING 2002), pp. 401-412.

xxxix. Thomas M. (2015). http:// www.dinf.ne.jp/ doc/ english/ asia/ resource/apdrj/ z13fm0100/ z13fm0108.html, by Dr. Maya Thomas \& Dr. MJ Thomas

xl. Torraco R. (2004). Theory-Building Research Methods, Torraco R. J., https:/ / books.google.co.ke/ books?hl=en\&lr=\&id=AyMZt9AodEEC\&oi=fnd\&pg=PA351\&dq=Torraco+R.+J.+～(2004), +Theory- Building+Research +Methods. \& ot.

xli. Vos P. (2009). Health through People's Empowerment: A Rights-Based Approach to Participation, Pol De Vos, Wim De Ceukelaire, Geraldine Malaise, Dennis Pérez, Pierre Lefèvre, Patrick Van der Stuyft, Health and Human Rights, Vol. 11, No. 1 (2009), pp. 23-35.

xlii. White S. (2005). Funding Large Rural Water Infrastructure Projects Author(s): Stephanie White, George Oamek and Jennifer Martinek source: Journal (American Water Works Association), Vol. 97, No. 4 (April 2005), pp. 30-32 Published by: American Water Works Association Stable URL: http:/ / www.jstor.org/ stable/ 41312453.

xliii. Wilcox D. (2006). The Guide to Effective Partition for community http:/ / www.globenet.org/ archives/ web/ 2006/ www.globenet.org/ horizon-local/ partnership/ wilcox.html. 